\title{
The Interplay between Working Capital Management and a Firm's Financial Performance across the Corporate Life Cycle
}

\author{
Zanxin Wang ${ }^{1}{ }^{(\mathbb{D}}$, Minhas Akbar ${ }^{2} \mathbb{D}$ and Ahsan Akbar ${ }^{3, *}$ \\ 1 School of Development Studies, Yunnan University, Kunming 650091, China; wzxkm@ynu.edu.cn \\ 2 Department of Management Sciences, COMSATS University Islamabad (Sahiwal Campus), Sahiwal 57000, \\ Pakistan; minhasakbar@cuisahiwal.edu.pk \\ 3 International Business School, Guangzhou College of South China University of Technology, \\ Guangzhou 510080, China \\ * Correspondence: akbar@gcu.edu.cn
}

Received: 1 February 2020; Accepted: 19 February 2020; Published: 22 February 2020

\begin{abstract}
The purpose of this study is to examine the impact of working capital management (WCM) and working capital strategy (WCS) on firm's financial performance across different stages of the corporate life cycle (CLC). We use Pakistani non-financial listed firms nested in 12 diverse industries over a period of 2005-2014 as the research sample and employ the hierarchical linear mixed (HLM) estimator, which can process multilevel data where observations are not completely independent. The empirical findings reveal that, overall, WCM is negatively associated with firm performance. However, this association is not static across different stages of a firm's life cycle. For example, a negative association is more pronounced at the introduction stage followed by growth and decline stages, whereas WCM does not significantly impact the performance of mature firms. Likewise, WCS also causes varying effects on the financial performance across the CLC. A conservative strategy at the introduction, growth, and decline stages negatively affects firm performance, suggesting that these firms should adopt an aggressive strategy. Nevertheless, management of sample firms did not account for the respective life cycle stage while formulating a WCM strategy, which can seriously compromise their financial sustainability. These findings suggest that firms require customized WCM policies and WCS to attain sustainable financial performance at each stage of firm life cycle. Thus, managers should not overlook the significant role of CLC stages in their financial planning to ensure the sustainable functioning of the enterprise.
\end{abstract}

Keywords: working capital management; working capital strategy; corporate life cycle; sustainable firm performance

\section{Introduction}

\subsection{Corporate Financial Sustainability}

In recent years, corporate sustainability (CS) has become ever more imperative for businesses as both shareholders and stakeholders are turning their focus towards critical role of sustainable corporate finance [1]. CS can broadly be categorized into three main pillars-social, environmental, and economic sustainability. Although, all of the three pillars are equally important, however, after the Global Financial Crises (GFC) of 2007-2008, which badly affected the financial sustainability of firms, corporate finance researchers have diverted their attention toward financial aspect of sustainability. The importance of corporate financial sustainability lies in the fact that it also directly affects the other two pillars (social and environmental) of sustainability. For instance, an International Monetary Fund 
(IMF) survey shows that GFC has rapidly escalated the global unemployment as over 210 million people were unemployed in 2010, an increase of more than 30 million people since 2007 (societal effect) [2]. Regarding environmental effects, Anbumozh and Bauer [3] found that although GFC results in some short-run environmental benefits however these benefits are much smaller when compared with the costs of various environmental conservation measures such as natural resources protection, energy saving and water preservation. Therefore, because of GFC, businesses and households have decreased spending on energy efficient measures, delayed the deployment of more efficient technology, reduced investment in research and development ( $\&$ \&) and energy efficient models and increased deforestation for timber or agricultural purposes among others. In a nutshell, as argued by Soppe [4], corporate financial sustainability is a multifaceted approach in which social, environmental, and financial elements are not only interrelated but also integrated.

\subsection{Working Capital Management and Corporate Life Cycle}

Working capital management (WCM) plays an imperative role in corporate financial sustainability as it can directly affect firm liquidity, profitability and solvency [5,6]. Mainly, working capital has four components-cash, inventories, account receivables, and account payables. Cash management refers to a certain amount of cash to fulfill day to day business needs while keeping the cost of cash holdings to a minimum level. A large volume of inventory is usually considered to be associated with higher sales volume and low transaction cost, thus stimulating profitability [7]. On the contrary, holding too much inventory may increase the possibility of product expiration, surplus warehouse cost and insurance premium [8]. While, maintaining a minimum level of inventories may increase the risk of stock outs and consequently loss of customers. Account receivables turnover refers to the time from goods being sold to the reception of cash from the customers. A prolonged time span may help to increase the sales volume of the firm, thereby increasing profitability. However, extended time period can also increase the leverage ratio of the firm which may lead towards an extra burden of financial cost. Account payables turnover is the time from goods being purchased and the payment of cash to the supplier. It will enable the firm to confirm the quality of the product or service before payment [9]. Payables may also reduce information asymmetry between firms and signal trustworthiness. However, protracted delays in the process of payment by the buyer can have negative consequences for the seller. Keeping in view, the optimal management of all these components is considered to have an influence on the profitability [10,11], risk [12], liquidity [5], solvency [6], and value of a firm [13,14]. Therefore, in a competitive corporate environment, efficient management of working capital (WC) is essential for all firm sizes functioning in any part of the world to harvest sustainable firm performance. However, WCM is even more crucial for firms operating in emerging and developing economies. As, such firms are generally smaller in size and have limited access to external finances, thus mainly rely on internal financial resources, trade credits, and short-term loans to support account receivables and inventories [15].

The concept of life cycle stages of a firm is not new to the corporate finance literature. Chandler [16] was among pioneers to propose that firms evolve through a life cycle, where technological and market forces play a substantial role in ensuing firm growth. More precisely, CLC theory propose that organizations are like living organisms that pass through foreseeable stages of life cycle and their resources, structure, strategies and capital requirements vary significantly at each stage of development. Studies also contend that the corporate life cycle (CLC) stage has a strong impact on its operating performance [17], financing [18], investment [19] and bankruptcy risk [20]. Moreover, any change in life cycle stage also influences a firm's financial health [20], consequently affecting its access to external financial resources. For instance, lenders feel reluctant to extend financing to a financially distressed firm. Even if they do so, it will come at a higher interest rate which will further deteriorate firm performance. 


\subsection{Working Capital Strategy and Corporate Life Cycle}

Several studies are available on the relationship between working capital strategy (WCS) and firm performance. Many of these studies suggest that an aggressive WCS is more suitable to enhance firm profitability [21,22]. Others postulate that a conservative WCS help firms to grow sales level and expand market share that will ultimately increase profitability [23]. Keeping these competing views in perspective, we postulate that CLC stages might play an important role to solve this puzzle by indicating that which strategy is most suitable for which stage of life cycle to boost firm performance and consequently firm financial sustainability in the long run. Firms at different stages of their life cycle have varying capital requirements to enhance their financial performance. Firms at the introduction, growth, and decline phases of their life cycle usually have limited resources; consequently, they may adopt an aggressive WCS to sustain financial performance. Contrarily, mature firms have sufficient funds to finance new projects and in the backdrop of limited future growth prospects they have surplus capital available in the form of retained earnings [24]. Thus, for mature firms, an over-investment in WC may not considerably impact firm performance.

Faff et al. [25] assert that a firm's investment, financing, and cash policies are interlinked and changes in line with its life cycle. Likewise, Habib and Hasan [26] claim that a firm's life cycle stage has a significant impact on its investment and financing activities and dividend payout policy. WC is directly linked with financing capabilities of firms [27] and these capabilities are not static at each stage of CLC [18]. This association provides a solid base to the argument that firms' financial soundness, financing capabilities, and associated performance varies with a change in CLC. However, the empirical findings are inconclusive as no attention has been paid to investigate the role of CLC stages in influencing WCM-performance relationship. The present research attempts to fill this void. This study makes an important contribution to the corporate finance literature by empirically revealing a link between CLC and WC theory. Hence, the objective of this paper is to reveal the impact of WCM and WCS on firm financial performance at each stage of corporate life cycle which will ultimately help the policy makers to devise customized strategies for respective CLC stage to attain sustainable performance over the years.

\subsection{Why Pakistan}

We select Pakistan as a case in this study due to several reasons. First, Pakistan's domestic credit to private sector to GDP ratio is merely 15.4\% [28]. Other South Asian countries such as India, Bangladesh, and Sri Lanka has a ratio of $52.2 \%, 43.9 \%$, and $40.7 \%$, respectively. Besides, Pakistan is also under-performing relative to other world economies such as the US (189\%), Australia (137.6\%), and the European Union (90.4\%) [28]. Likewise, non-performing loans of Pakistani firms (11.3\%) are higher than those of India (5.8\%), Sri Lanka (3.24\%), the US (1.5\%), Australia (1\%), and the European Union (5.4\%) [28]. Second, in Pakistan, the average WC financing through banks is as low as $8.6 \%$, whereas in other regional economies such as Bangladesh, Sri Lanka, and India, this number is $29.9 \%$, $40.6 \%$, and $36.4 \%$, respectively [29]. Finally, the interest rate, which plays a significant role in WC financing, is also higher in Pakistan (8.32\%) as compared to developed countries such as the US $(2.4 \%)$, New Zealand (2.5\%), and Australia (5.9\%) [28]. All these statistics illustrate that Pakistan's corporate sector has limited access to external finance and also has to endure a higher financing cost on borrowed capital that can really deteriorate a firm's financial performance. Hence, this macro-economic setting makes Pakistan an interesting case for investigation of the proposed relationship.

\section{Literature Review and Hypothesis Development}

Corporate finance literature has well recognized the vital role of WCM in determining the financial performance of an enterprise. A list of researchers has found significant relationship between WCM and corporate profitability [23,30]. However, the question that still remains unanswered is the true direction of this relationship. One possible reason of this bi-directional association could be that studies 
were conducted in different countries and in varying contexts, with diverse economic conditions which ultimately leads to competing findings. Notwithstanding, the literature in the context of Pakistan also unveils inconsistent results. Sial and Chaudhry [31] and Arshad and Gondal [32] found a significantly negative relationship between WCM and firm profitability. Contrarily, Iqbal and Zhuquan [33] and Tahir and Anuar [34] report a positive relationship between WCM and firm profitability.

Recently, Baños-Caballero et al. [30] revealed that for each firm there exist an optimal level of WC and up till that optimal level investment in WC earns higher profitability. Conversely, investment in WC beyond that level leads to a decrease in firm performance. Moreover, Enqvist et al. [35] concluded that the influence of business life cycle on the WCM-performance linkage is more significant during economic downturns compare to economic booms. Tsuruta and Economy [36] observe that Japanese firms were slow in making adjustments in their WC during the global financial crisis of 2008. Additionally, the negative association between excess WC and firm profitability gets more pronounced during the crisis period.

In a study of 300 microfinance institutions, Bogan et al. [37] observed that such institutions attain sustainability through a "life cycle" of organizational development. Furthermore, their study highlighted the management of capital structure and financing instruments as the deciding factors of financial sustainability. Likewise, Bonazzi and Iotti [38] analyzed the relationship between interest coverage ratio, which is a financing indicator, and the financial sustainability of dairy firms in Italy. The conventional cash flow analysis reveals that sample firms face difficulty in generating profitable outcomes which can negatively affect financial sustainability. From a WCM standpoint, Njeri et al. [39] examined the association between the efficiency in the management of working capital accounts and financially sustainable performance of government owned entities in Kenya. The study findings assert that WCM was the primary factor in influencing the financial sustainability of such firms. However, it still remains unclear that how CLC affect this association as no empirical attempt has been made so far to explore the impact of change in CLC on WCM and firm financial performance nexus.

CLC theory proposes that firms pass through a series of foreseeable development phases and that the strategies, structures, risk taking, and resources of the firm vary meaningfully with the change in its development stage [40]. At the introduction phase, firms require higher investment in fixed assets to make the market less attractive for new entrants [41]. Introduction firms generally have net cash out flows [42] with relatively low profits [43] and higher bankruptcy risk [20]. However, Carpenter and Petersen [44] evidenced that the major element that constraints the growth during introductory phase of a firm is limited internal finance. Moreover, due to higher information asymmetry introduction firms face a dearth of external finances [45]. Thus, mangers of such firms tend to borrow external capital at higher interest rates [46].

Growth firms are characterized by high sales growth, distinctive competencies, and diversified product lines [40]. Firms at this stage heavily rely on external financing as the demand for capital is higher than their ability to generate funds from internal sources [47]. However, as compare to introduction firms, cost of equity capital and risk of going bankrupt is lower for growth firms [20,48].

The mature stage of a firm's life cycle gets underway when the growth in sales begins to slow down [49]. During this stage, sales levels stabilize, and firms are relatively conservative and prefer to preserve what they have gained [50]. Though mature firms can borrow on lower rates, the demand for external capital decreases substantially as cash flows generated from internal operations are sufficient to meet the financial requirements [24]. Decline phase of CLC is characterized by shrinking profits due to decline in sales volume [49]. To overcome this problem, firms tend to increase investment to spur growth [51] and spend more on research and development in an attempt to regain market share [52]. Besides, decline firms with substantial debt levels face escalated risk of bankruptcy [20].

However, previous research postulates competing arguments regarding the shake-out stage. Some describe it by rapidly expanding large size firms [40]. Other explain it with declining product line and falling prices [53]. Therefore, consistent with Hasan et al. [20] and Akbar et al. [48], we use shake-out stage as a benchmark to compare the results of other stages of CLC. 
It can be inferred from the above discussion that firms during introduction, growth and decline phases of their life cycle need massive external financing to meet their capital requirements and to pay interest on the borrowed capital. However, as compare to introduction stage, growth firms have an easy and less costly access to external finance. Consequently, an over-investment in WC will deteriorate the financial sustainability of firms in the midst of introduction, growth, or decline. However, the perceived intensity of this negative influence is lesser for growth firms due to surplus funds available in retained earnings. Therefore, excess funds tied up in WC may have a relatively smaller impact on the profitability of such firms. Hence, we developed the following hypothesis.

Hypothesis 1. WCM is expected to have a negative association with firm profitability at the introduction, growth and decline stages of the life cycle.

One way to elaborate the word strategy is "the dynamics of the firm's connection with its outer environment in which the desired steps are taken to achieve its objectives and to enhance performance by the rational use of resources" [53]. This definition fits best in the context of WCS as it is the centerpiece of the overall firm performance. While the environment might also be considered as a factor affecting WC [54]. Firms pursue either an aggressive or a conservative WCS 23 and this strategic choice can significantly affect their risk and profitability [55]. Firms adopting a conservative strategy prefer to invest heavily in WC to enhance sales volume by increasing inventory and receivables to enhance profitability. An increase in inventory volume is associated with the reduction in risk of stock-outs [21], reduced supply costs, and price variations [56]. Likewise, an increase in receivables can help to increase sales as it allows customers more time to make payments. However, high investments in WC can also escalate firms' bankruptcy risk [57]. Contrarily, firms adopting aggressive WCS prefer to invest less in WC accounts. These firms tend to reduce investments in inventory and receivables [58] or may increase current liabilities to finance current assets [23]. By decreasing inventory holding period, firms can optimize profitability as this practice can reduce warehouse, insurance, and theft costs. Besides, an aggressive WCS can also maximize profitability by reducing receivables period, which will increase the net cash available to finance daily operations, hence decreasing the need for expensive external financing [59].

The question, however, still remains unclear as to whether corporate managers should take into consideration the respective stage of CLC while choosing a WCS? We contend that CLC theory may help to explain the appropriate WCS relative to each stage of firm life cycle, that will sustain firm financial health in the long run. As introduction, growth and decline firms may prefer an aggressive WCS to curtail their external financing requirements. Thus, the following hypothesis emerges.

Hypothesis 2. A conservative WCS is expected to be negatively linked with firm profitability at the introduction, growth, and decline stages of the CLC.

\section{Data and Methodology}

\subsection{Sample and Data Collection}

The data for this study consists of all the non-financial listed firms in Pakistan covering a period of 10 years (2005-2014). A total of 396 non-financial firms nested in 12 industries were listed on Pakistan stock exchange. However, several firms had missing observations in their reported data. Hence, only firms with consecutive five years of published data were made part of the final sample. This practice resulted in an unbalanced panel of 291 firms with 2371 firm-year observations. The data to calculate dependent, independent, firm level, and industry level variables was obtained from the Balance Sheet Analysis (BSA) published by the State Bank of Pakistan. Cash-flows data to compute CLC stages was accessed from OSIRIS data-base. Data of Macro-economic variables (GDP growth and inflation) was retrieved from the World Development Indicators (WDI) available at the World Bank's website. Data 
on industrial growth was extracted from the CIA World fact book. Moreover, annual reports of firms were also consulted to make up for the missing observations.

\subsection{Measurement of Variables}

\subsubsection{Firm Financial Performance}

Following previous studies, return on assets (ROA) is used as a measure of firm financial performance.

\subsubsection{Corporate Life Cycle}

We follow a more recent methodology put forward by Dickinson [52] which entails a five-staged (introduction, growth, maturity, shake-out, and decline) cyclical measure of CLC based on its cash flow patterns. Dickinson [52] argues that cash flows of a firm capture differences in its growth, profitability, allocation of resources and risk. Thus, by using cash flow from operating (CFO), investing (CFI) and financing (CFF) activities one can classify the firms into various stages of the life cycle.

The methodology is founded on the following cash flow pattern:

Introduction: if $\mathrm{CFO}<0, \mathrm{CFI}<0$ and $\mathrm{CFF}>0$;

Growth: if $\mathrm{CFO}>0, \mathrm{CFI}<0$ and $\mathrm{CFF}>0$;

Mature: if $\mathrm{CFO}>0, \mathrm{CFI}<0$ and $\mathrm{CFF}<0$;

Decline: if $\mathrm{CFO}<0, \mathrm{CFI}>0$ and $\mathrm{CFF} \leq$ or $\geq 0$; and

Shake-out: Any pattern other than those of mentioned above.

\subsubsection{Working Capital management}

The net trade cycle (NTC) is used to measure the WCM of a firm [60]. It is calculated as (receivable days + days inventory - days in accounts payable).

\subsubsection{Working Capital Strategy}

To measure WCM strategy of a firm, first, we compute Net Working Capital (NWC) for each firm-year as (inventories + receivables - trade creditors). Subsequently, NWC is scaled by annual sales of respective firm to obtain NWC to sales ratio. Afterward, average NWC to sales ratio is calculated for each of 12 industries individually to compare the NWC to sales ratio of each company with the respective industry average. Firms with a NWC to sales ratio lower than the industry average are designated as pursuing aggressive WCM strategy while those with a ratio above the industry average are deemed as adopting a conservative strategy. A similar approach is used in reference [61].

The control variables used in this study are consistent with the relevant literature. A complete description of the variables and their computation method is provided in Appendix A.

\subsection{Modes and Methodology}

The structure of our data set is hierarchical in nature, consisting of 291 firms nested in 12 industries. From an econometric modeling perspective, observations at the firm-level are grouped under higher units (e.g., industries) so analyzing the data through OLS based regression can cause problems, such as biased estimates of coefficient's standard errors and wrongfully interpreting significance of the explanatory variables [62]. Hence, we make full use of a recently developed modeling technique, HLM estimation that can process multilevel data where observations are not totally independent, for an overview of HLM, see [63]. In this paper the set of firms within industries form the base level observations, whereas industries serve as higher-level observations. Alternatively, panel-based regression models are employed to cope with the issue of heterogeneity [64]. 


\subsection{Empirical Model}

We have constructed two different models to separately examine the impact of WCM and WCS at different stage of CLC on firm financial performance.

In Equation (1), ROA is used to proxy firm performance and NTC measures WCM. Whereas, NTC*FLCS is an interaction variable employed to examine the effects of firms' life cycle stage on the relationship between WCM and firm performance. $\beta_{2}, \beta_{3}, \beta_{4}$ and $\beta_{5}$ denote coefficients of introduction ${ }^{*} \mathrm{NTC}$, growth ${ }^{*} \mathrm{NTC}$, mature*NTC, and decline*NTC, respectively.

$$
\begin{aligned}
\text { ROA }_{i, t} & =\alpha_{\mathrm{O}}+\beta_{1}, \mathrm{NTC}_{\mathrm{i}, \mathrm{t}} \\
& +\sum_{\mathrm{k}=2}^{5} \beta_{\mathrm{k}} \mathrm{NTC}_{\mathrm{i}, \mathrm{t}} * \mathrm{FLCS}_{\mathrm{k}, \mathrm{i}, \mathrm{t}}+\beta_{6} \mathrm{FSIZE}_{\mathrm{i}, \mathrm{t}} \\
& +\beta_{7} \mathrm{LEVG}_{\mathrm{i}, \mathrm{t}}+\beta_{8} \mathrm{MTB}_{\mathrm{i}, \mathrm{t}} \\
& +\beta_{9} \mathrm{SGROWTH}_{\mathrm{i}, \mathrm{t}}+\beta_{10} \mathrm{CAG}_{\mathrm{i}, \mathrm{t}} \\
& +\beta_{11} \mathrm{INDCOM}_{\mathrm{i}, \mathrm{t}}+\beta_{12} \mathrm{INDGR}_{\mathrm{i}, \mathrm{t}} \\
& +\beta_{13} \mathrm{GGDP}_{\mathrm{i}, \mathrm{t}}+\beta_{14} \mathrm{INF}_{\mathrm{i}, \mathrm{t}}+\varepsilon_{\mathrm{i}, \mathrm{t}}
\end{aligned}
$$

In Equation (2), ROA is used to measure firm performance. WCS is a dummy variable which reflects WCM strategy of a firm. Firms with conservative WCS are coded as "1" and firms with aggressive WCS are coded as "0." Here, $\beta_{2}, \beta_{3}, \beta_{4}$ and $\beta_{5}$ denote introduction ${ }^{*} W C S$, growth ${ }^{*} W C S$, mature*WCS, and decline*WCS, respectively.

$$
\begin{aligned}
& \mathrm{ROA}_{i, \mathrm{t}}=\alpha_{\mathrm{O}}+\beta_{1}, \mathrm{WCS}_{\mathrm{i}, \mathrm{t}} \\
& +\sum_{\mathrm{k}=2}^{5} \beta_{\mathrm{k}} \mathrm{WCS}_{\mathrm{i}, \mathrm{t}} * \mathrm{FLCS}_{\mathrm{k}, \mathrm{i}, \mathrm{t}}+\beta_{6} \text { FSIZE }_{\mathrm{i}, \mathrm{t}} \\
& +\beta_{7} \text { LEVG }_{i, t}+\beta_{8} \text { MTB }_{i, t} \\
& +\beta_{9} \text { SGROWTH }_{i, t}+\beta_{10} \mathrm{CAG}_{\mathrm{i}, \mathrm{t}} \\
& +\beta_{11} \mathrm{INDCOM}_{\mathrm{i}, \mathrm{t}}+\beta_{12} \mathrm{INDGR}_{\mathrm{i}, \mathrm{t}} \\
& +\beta_{13} \mathrm{GGDP}_{\mathrm{i}, \mathrm{t}}+\beta_{14} \mathrm{INF}_{\mathrm{i}, \mathrm{t}}+\varepsilon_{\mathrm{i}, \mathrm{t}}
\end{aligned}
$$

Keeping in view the presence of large outliers in our sample, we winsorized all the firm level variables at $4 \%$ level in both tails. Besides, considering that both the dependent and independent variables consist of financial ratios for the same time period, the issue of endogeneity might arise. Therefore, we use one period lag of the financial ratios as independent variables to address this problem.

\section{Results and Discussion}

\subsection{Descriptive Statistics}

Life cycle wise descriptive statistics are presented in Table 1. On average, sample firms generate lower profits during the introduction stage (0.40), that increases at growth stage (5.74) and reached at its peak during the mature (9.53) stage of CLC. However, profitability tends to decline at the shake-out stage (5.02) and reached at the minimum level during decline (0.013) stage of CLC. Mean value for NTC is 85.66 , it depicts that on average, firms took 85 days to convert their receivables and inventories into cash.

Life cycle-wise statistics reveal that on average introduction, growth, mature and decline firms took 90 days, 77 days, 80 days, and 113 days, respectively, to convert their receivables and inventories into cash. 
Table 1. Life cycle wise descriptive statistics.

\begin{tabular}{ccccccccccc}
\hline Variables & N & Mean & S.D & $\begin{array}{c}\text { 5th } \\
\text { Percentile }\end{array}$ & $\begin{array}{c}\text { 95th } \\
\text { Percentile }\end{array}$ & Intro & Growth & Mature & $\begin{array}{c}\text { Shake } \\
\text {-Out }\end{array}$ & Decline \\
\hline ROA & 2662 & 5.87 & 11.19 & -13.4 & 30.41 & 0.403 & 5.74 & 9.17 & 5.02 & 0.0135 \\
NTC & 2371 & 85.66 & 70.95 & 2.19 & 251.1 & 90.27 & 77.63 & 80.04 & 95.6 & 113.03 \\
FSIZE & 2371 & 13.38 & 2.09 & 10.0 & 17.25 & 12.95 & 13.57 & 13.62 & 13.3 & 12.45 \\
LEVG & 2371 & 1.73 & 1.96 & -1.58 & 6.31 & 2.14 & 1.69 & 1.71 & 1.49 & 1.38 \\
MTB & 2371 & 0.978 & 1.07 & -0.077 & 3.65 & 0.852 & 0.912 & 1.08 & 0.995 & 0.695 \\
SGROW & 2371 & 0.149 & 0.310 & -0.408 & 0.804 & 0.160 & 0.182 & 0.173 & 0.091 & -0.012 \\
FAGR & 2371 & 0.153 & 0.303 & -0.105 & 1.01 & 0.215 & 0.218 & 0.124 & 0.117 & 0.104 \\
INDCOM & 2662 & 1192 & 1147 & 232 & 3980 & 986.7 & 1163 & 1209 & 1417 & 1220 \\
INDGR & 2662 & 4.38 & 3.09 & -1.90 & 10.7 & 4.67 & 4.91 & 4.13 & 4.42 & 3.70 \\
GGDP & 2662 & 3.87 & 1.78 & 1.6 & 7.7 & 3.81 & 4.36 & 3.79 & 3.80 & 3.42 \\
INF & 2662 & 11.01 & 3.93 & 7.2 & 20.3 & 11.6 & 10.2 & 10.9 & 11.1 & 11.3 \\
\hline
\end{tabular}

Figures 1 and 2 present average ROA and NTC across different stages of firm life cycle. In Figure 1, statistics reveal that sample firms failed to sustain their financial performance when they transit from one stage to another stage of life cycle. Highest value of ROA (9.17) at mature stage is in line with the prediction as these firms have achieved the economies of scale and enjoy higher profitability. On the contrary, profitability of decline (0.013) firm is lowest followed by the introduction, shake-out and growth stage firms. Overall, firm performance shows an inverted-“ $\mathrm{V}^{\prime \prime}$-shaped trend across CLC stages.

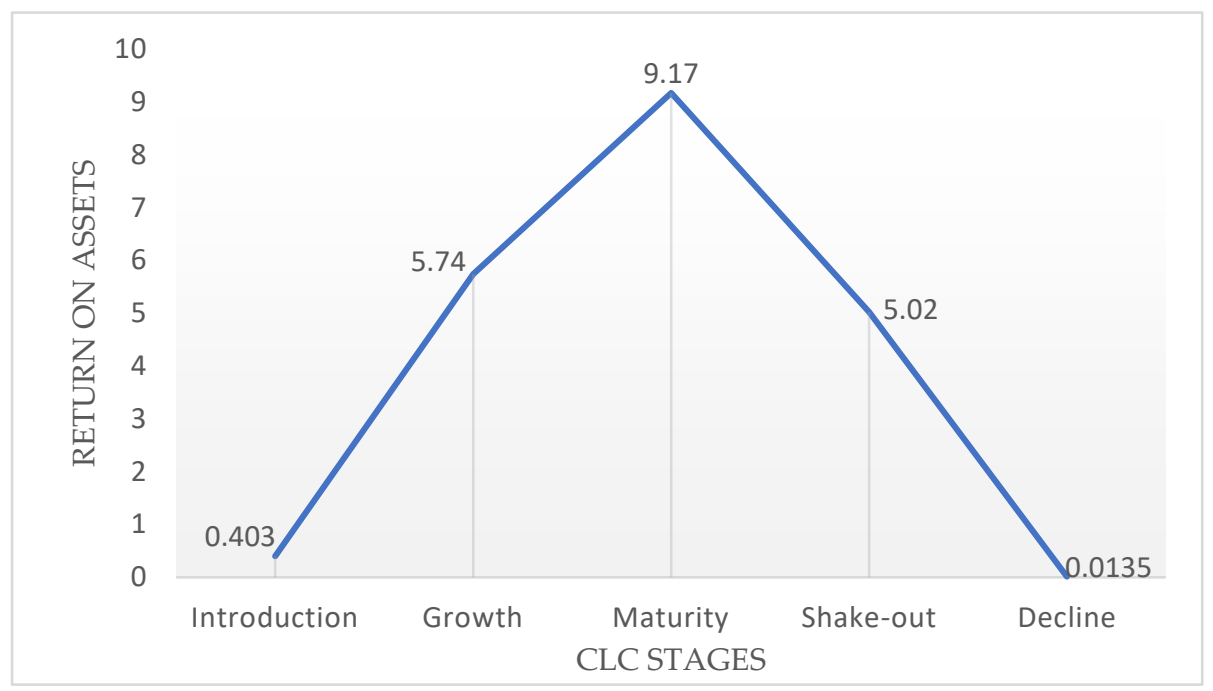

Figure 1. Average return on assets across corporate life cycle (CLC) stages.

Surprisingly, the results of Figure 2 show that firms with the lowest profitability (decline- and introduction-staged firms) are managing their NTC more conservatively, which is seriously hampering corporate profitability. This indicates that despite financial constraints, introduction and decline firm's WCM is quite inefficient as managers failed to account for the crucial role of CLC stages in WCM. Hence due to lack of coordination between WCM policies and CLC such firms may not be financially sustainable in the long term. 


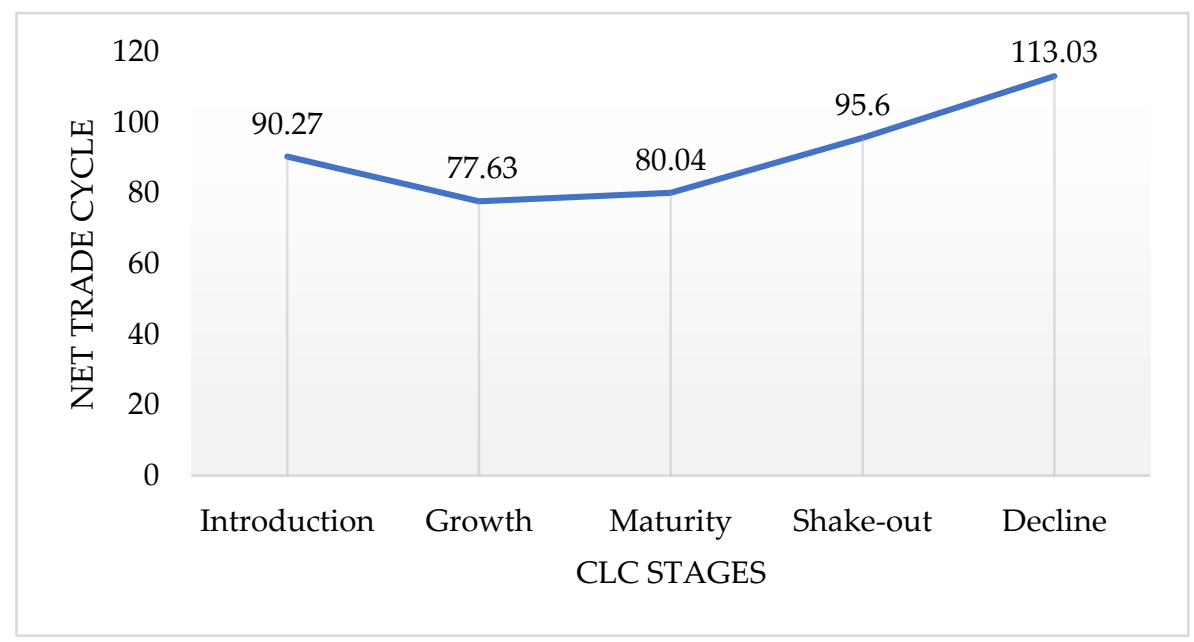

Figure 2. Average net trade cycle (NTC) across CLC stages.

Table 2 presents the results of pair-wise correlation. ROA and NTC have a negative correlation which means that any increase in NTC decreases the profitability of sample firms. Besides, NTC also has a negative correlation with firm size and sales growth which contradicts with the notion that firms can increase sales by extending credit period. Likewise, a negative association between firm size and leverage predicts that small firms rely heavily on external financing. Furthermore, we employ VIF diagnostics proposed by Kennedy [65], and the values are above 10 in all cases which rules out the possibility of multicolliniarity.

Table 2. Correlation matrix.

\begin{tabular}{|c|c|c|c|c|c|c|c|c|c|c|c|}
\hline Variables & ROA & NTC & SIZE & LEV & МТВ & GROW & CAG & INDCOM & INDGR & GGDP & INF \\
\hline ROA & 1 & & & & & & & & & & \\
\hline NTC & -0.17 & 1 & & & & & & & & & \\
\hline SIZE & $0.34 *$ & -0.20 * & 1 & & & & & & & & \\
\hline LEVG & $-0.17^{*}$ & -0.00 & $-0.08 *$ & 1 & & & & & & & \\
\hline МТВ & $0.32 *$ & -0.19 * & 0.55 * & $0.16^{*}$ & 1 & & & & & & \\
\hline GROW & 0.11 * & -0.20 * & 0.07 * & 0.05 * & 0.09 * & 1 & & & & & \\
\hline CAG & $0.04 *$ & -0.01 & 0.13 * & -0.00 & $0.09 *$ & 0.08 * & 1 & & & & \\
\hline INDCOM & 0.12 * & -0.03 & 0.35 * & $-0.13 *$ & $0.22 *$ & 0.00 & $0.08 *$ & 1 & & & \\
\hline INDGR & $0.08^{*}$ & -0.02 & 0.01 & -0.03 & 0.03 & $0.06^{*}$ & $0.12 *$ & 0.01 & 1 & & \\
\hline GGDP & 0.07 * & 0.00 & $0.07 *$ & $-0.07 *$ & 0.03 & $0.06 *$ & 0.01 & 0.02 & $0.32 *$ & 1 & \\
\hline INF & -0.06 * & -0.00 & -0.02 & $0.08^{*}$ & $0.08 *$ & $-0.06^{*}$ & 0.02 & -0.02 & -0.23 * & $-0.84 *$ & 1 \\
\hline
\end{tabular}

Note: * indicates $5 \%$ significance level.

\subsection{Regression Results and Discussion}

Table 3 reports the association between NTC and ROA at different stages of its life cycle by using hierarchical linear model.

The results of HLM regressions to examine the perceived association between WCM and firm performance at different stages of its life cycle are presented in Table 3. Results demonstrate that regardless of life cycle stages, NTC has a significantly $(p<0.01)$ negative coefficient with ROA $(-0.0179)$. This suggests that an increase in NTC decreases the profitability of sample firms. Similar findings were reported by Pais and Gama [22]. Life cycle statistics indicate that firms are unable to sustain their performance across their life cycle as firms during introduction and decline stages have a negative and significant $(p<0.01)$ relationship with profitability. These evidences provide support to the notion that firms face scarcity of financial resources during the introduction and decline stages and fulfill their financial needs by borrowing from external sources. Thus, any extra investment in WC decreases profitability of such firms and negatively affect their sustainable financial development. Growth ${ }^{*}$ NTC is also negatively associated with ROA $(p<0.05)$. However, the coefficient at growth stage $(-0.011)$ is 
smaller than that of the introduction stage $(-0.013)$ which depicts that, although an increase in NTC decreases firm profitability, however the degree of this association gets weaker because of higher sales growth with accumulated profits and improved investor confidence. Besides, WC level of mature firms has an insignificant coefficient with profitability. It strengthens the proposition that mature firms have stronger financial sustainability as they have surplus funds available with limited future growth prospects thus an extra investment in WC do not harm their profitability. It is worth noting that $43 \%$ of the sample consists of mature firms (see Appendix B).

Table 3. Baseline regression models.

\begin{tabular}{|c|c|c|c|}
\hline \multirow{2}{*}{ Variables } & \multirow{2}{*}{ Expected Sign } & \multirow{2}{*}{$\begin{array}{c}\text { Model } \\
\text { (1) }\end{array}$} & \multirow{2}{*}{$\begin{array}{c}\text { Model } \\
(2)\end{array}$} \\
\hline & & & \\
\hline NTC & - & $\begin{array}{c}-0.0179 * * * \\
(-5.14)\end{array}$ & \\
\hline NTC $\times$ Birth & - & & $\begin{array}{c}-0.0130^{* * *} \\
(-4.82)\end{array}$ \\
\hline NTC $\times$ Growth & - & & $\begin{array}{c}-0.0114^{* *} \\
(-2.49)\end{array}$ \\
\hline NTC $\times$ Mature & + & & $\begin{array}{c}0.00158 \\
(0.63)\end{array}$ \\
\hline NTC $\times$ Decline & - & & $\begin{array}{c}-0.00688^{* * *} \\
(-3.40)\end{array}$ \\
\hline LEVG & - & $\begin{array}{c}-0.582 * * * \\
(-5.24)\end{array}$ & $\begin{array}{c}-0.612^{* * *} \\
(-5.53)\end{array}$ \\
\hline MTB & + & $\begin{array}{c}1.473^{* * *} \\
(6.03)\end{array}$ & $\begin{array}{c}1.630^{* * *} \\
(6.80)\end{array}$ \\
\hline SGROW & + & $\begin{array}{c}1.147^{* *} \\
(2.08)\end{array}$ & $\begin{array}{c}1.455^{* * *} \\
(2.68)\end{array}$ \\
\hline CAG & - & $\begin{array}{c}-1.461^{* * *} \\
(-2.62)\end{array}$ & $\begin{array}{c}-1.121^{* *} \\
(-1.99)\end{array}$ \\
\hline INDCOM & + & $\begin{array}{c}0.00104^{* * * *} \\
(2.66)\end{array}$ & $\begin{array}{c}0.00108^{* * *} \\
(3.14)\end{array}$ \\
\hline INDGR & + & $\begin{array}{c}0.236^{* * *} \\
(3.56)\end{array}$ & $\begin{array}{c}0.231^{* * *} \\
(3.47)\end{array}$ \\
\hline INF & - & $\begin{array}{c}-0.141^{* * *} \\
(-3.44)\end{array}$ & $\begin{array}{c}-0.145^{* * *} \\
(-3.54)\end{array}$ \\
\hline Constant & & $\begin{array}{c}6.076^{* * *} \\
(5.77)\end{array}$ & $\begin{array}{c}4.866^{* * *} \\
(5.71)\end{array}$ \\
\hline$N$ & & 2371 & 2371 \\
\hline
\end{tabular}

Robust $t$-statistics are in the brackets while, ${ }^{* * *}$ and ${ }^{* *}$ indicates $1 \%, 5 \%$, and $10 \%$ significance level, respectively.

Table 4 reports the association between WCM strategy and firm performance at different stages of its life cycle using a hierarchical linear mixed models methodology.

The results concerning $\mathrm{H} 2$ are reported in Table 4. A conservative WCS has a negative and statistically significant $(p<0.01)$ coefficient with firm profitability. Thus, firms can increase their performance by adopting an aggressive WCM strategy. Life cycle wise statistics indicate that for introduction $(p<0.01)$, growth $(p<0.05)$ and decline $(p<0.05)$ firms, a conservative WCS decreases firm profitability. Moreover, coefficient at growth stage $(-1.84)$ is lower than that of the introduction stage (-3.14), implying that, although both introduction and growth firms have negative association with conservative WCS; however, this association is more pronounce for introductory firms. These findings are in line with the proposition that firms during the introduction phase have fewer funds available to finance their operations [66]. Likewise, growth and decline firms also post a negative coefficient between conservative WCS and ROA which posit that such firms shall pursue an aggressive WCS for sustainable functioning of their financial operations. Nonetheless, insignificant relationship 
between WCS and ROA at mature stage reinforce earlier results that mature firms experience stable sales with surplus cash flows [24]. Thus, adoption of either strategy does not substantially influence their financial sustainability. In a nutshell, the findings of Tables 3 and 4 strengthens the proposition that firms need a different level of WC and a different WCS to sustain their financial performance across varying stages of CLC.

Table 4. Working capital strategy (WCS) and firm performance at different life cycle stages.

\begin{tabular}{|c|c|c|c|}
\hline \multirow{2}{*}{ Variables } & \multirow{2}{*}{ Expected Sign } & \multirow{2}{*}{$\begin{array}{c}\text { Model } \\
\text { (1) }\end{array}$} & \multirow{2}{*}{$\begin{array}{c}\text { Model } \\
(2)\end{array}$} \\
\hline & & & \\
\hline WCS & - & $\begin{array}{c}-1.945^{* * *} \\
(-4.20)\end{array}$ & \\
\hline WCS $\times$ Birth & - & & $\begin{array}{c}-3.146^{* * *} \\
(-4.63)\end{array}$ \\
\hline WCS $\times$ Growth & - & & $\begin{array}{c}-1.840 \\
(-2.28)\end{array}$ \\
\hline WCS $\times$ Mature & + & & $\begin{array}{l}0.109 \\
(0.19)\end{array}$ \\
\hline WCS $\times$ Decline & - & & $\begin{array}{c}-2.840^{* *} \\
(-2.56)\end{array}$ \\
\hline LEVG & - & $\begin{array}{c}-0.587^{* * *} \\
(-5.28)\end{array}$ & $\begin{array}{c}-0.593^{* * *} \\
(-5.35)\end{array}$ \\
\hline МТВ & + & $\begin{array}{c}1.555^{* * * *} \\
(6.40)\end{array}$ & $\begin{array}{c}1.619 * * * \\
(6.75)\end{array}$ \\
\hline SGROWTH & + & $\begin{array}{c}1.436^{* * *} \\
(2.64)\end{array}$ & $\begin{array}{c}1.497^{* * *} \\
(2.76)\end{array}$ \\
\hline CAG & - & $\begin{array}{c}-1.426^{* *} \\
(-2.55)\end{array}$ & $\begin{array}{c}-1.188^{* *} \\
(-2.11)\end{array}$ \\
\hline INDCOM & + & $\begin{array}{c}0.000999^{* * *} \\
(2.65)\end{array}$ & $\begin{array}{c}0.00104^{* * * *} \\
(3.00)\end{array}$ \\
\hline INDGR & + & $\begin{array}{c}0.242^{* * *} \\
(3.64)\end{array}$ & $\begin{array}{c}0.218^{* * *} \\
(3.27)\end{array}$ \\
\hline INF & - & $\begin{array}{c}-0.140^{* * *} \\
(-3.42)\end{array}$ & $\begin{array}{c}-0.145^{* * *} \\
(-3.53)\end{array}$ \\
\hline Constant & & $\begin{array}{c}5.154^{* * * *} \\
(5.34)\end{array}$ & $\begin{array}{c}4.915^{* * *} \\
(5.78)\end{array}$ \\
\hline $\mathrm{N}$ & & 2371 & 2371 \\
\hline
\end{tabular}

Robust $t$-statistics is in the brackets while, ${ }^{* * *}$ and ${ }^{* *}$ indicate $1 \%, 5 \%$, and $10 \%$ significance level, respectively.

We also applied panel fixed-effects regression for robustness, and results were consistent with Tables 3 and 4 . Results are available with the authors and are not presented here to conserve space.

\section{Conclusions and Policy Implications}

This paper sheds light on the WCM and firm performance nexus relative to its life cycle stages. We posit that firms at various stages of life cycle have different capital requirements and their ability to raise funds from external sources keeps changing across the CLC. Hence, investment in WC accounts has varied implications for sustainable corporate performance during each stage of CLC. Empirical results reveal that regardless of CLC stages, higher investment in WC has a negative impact on firm performance.

However, higher funds tied up in WC at introduction, growth and decline stages were found to be associated with poor firm performance. This outcome is consistent with our proposition that introduction firms face scarcity of financial resources due to information asymmetry and difficulty to predict future growth prospects, such firms borrow external capital at higher rates hence excessive investments in WC at these CLC stages can seriously hamper corporate sustainability. Although 
growth firms experience higher expansion in sales and profits, however, they also need additional financing to fuel fast-paced growth. Likewise, decline firms are known for heavy investment in a turnaround attempt, but non-diversified managerial approach usually leads to investment in negative NPV projects which results in decline in sales and profit margins. Therefore, an over-investment in WC during these three phases of life cycle require firms to borrow from external sources to finance the WC which eventually cause a decline in firm performance. It is worth mentioning that, although the WCM performance relationship is negative for introduction $(-0.013)$, growth $(-0.011)$, and decline $(-0.006)$ stages, the coefficients reveal that intensity of this negative association vary significantly with a change in the corresponding CLC stage. Moreover, extra funds tied up in WC do not significantly affect the performance of mature firms, which can be attributed to the availability of surplus cash flows and strong financial standing of such firms.

Besides, we also examine the association between WCS and firm performance subject to its corresponding life cycle stage. The findings indicate that, a conservative WCS negatively affects firm performance. Life cycle-wise results show that the performance of introduction, growth and decline firms is negatively associated with a conservative strategy. It implies that management of such firms should adopt an aggressive WCM strategy to increase profitability. Consistent with the expectations, performance of mature firms has no significant association with either of WCS. Taken together, our findings reveal that firms require more customized WCM and WCS to attain sustainable financial performance at each stage of corporate life cycle. Particularly, in developing economies such as Pakistan where financial markets are under-developed and access to external finance is limited, the selection of an appropriate WCS in relation to the CLC stage can substantially help such firms to manage their financial resources more prudently for sustainable growth of the enterprise. This research results reveal a link between the WCM and firm's financial performance across the CLC stages and assert that firms need a customized WCS at each stage of CLC for sustainable financial performance. The findings of this study have useful implications for corporate stakeholders. In a country like Pakistan, where firms face significant external financing constraints it is imperative to adjust WCS at each stage of CLC for sustainable functioning of the enterprise operations. Hence, managers shall not overlook the significant influence of CLC in their short-range financial decisions as ignoring this association can seriously compromise the firm's financial sustainability. Likewise, investors and creditors shall keep a check on firm's ability to efficiently align its WCS with the respective life cycle stage so as to avoid investing in firms with unsustainable corporate policies. Though the study findings can only be generalized in the context of developing countries with similar stage of economic development. Future research in this domain can explore the similar relationship in the context of advanced countries. Moreover, it will be interesting to observe the role of macroeconomic factors such as business cycle and economic growth on the interplay between WCM and sustainable corporate performance.

Author Contributions: Conceptualization, M.A. and Z.W.; methodology, M.A.; formal analysis, M.A.; writing_original draft preparation, A.A.; review and editing, Z.W.; funding acquisition, Z.W. All authors have read and agreed to the published version of the manuscript.

Funding: This research was funded by the energy transition and sustainability project of Yunnan University, China (C176240202015).

Acknowledgments: We thank the anonymous reviewers for their valuable suggestions. We also thank Yunnan University for funding the open access of this article.

Conflicts of Interest: The authors declare no conflict of interest. 


\section{Appendix A}

Table A1. Variables definition.

\begin{tabular}{|c|c|c|}
\hline Variable & Label & Calculation \\
\hline$\frac{\text { Dependent variable: }}{\text { Return on assets }}$ & ROA & Net profit before tax scaled by total assets at the end of fiscal year \\
\hline$\frac{\text { Firm level Control variables: }}{\text { Firm size }}$ & FSIZE & Natural log of firms' market value of equity \\
\hline Leverage & LEVG & $\begin{array}{l}\text { (Current liabilities + non-current liabilities)/Share holders' } \\
\text { equity }\end{array}$ \\
\hline Market to book ratio & МТВ & Market value of equity/book value of equity \\
\hline Sales growth & SGROW & $\begin{array}{l}\text { Sales growth is measured by the ratio of current year sales to } \\
\text { lagged sales }\end{array}$ \\
\hline Capital assets growth rate & CAG & $\begin{array}{l}\text { current years' fixed assets scaled by lagged fixed assets } \\
\text { Industry competition is measured by using Herfindahl index. It }\end{array}$ \\
\hline$\frac{\text { Industry level Control variables: }}{\text { Industry competition }}$ & INDCOM & $\begin{array}{l}\text { is calculated as sum of squares of the market share of firms } \\
\text { within an industry. Higher value of index suggests high market } \\
\text { concentration while low level of competition. }\end{array}$ \\
\hline$\frac{\text { Country level Control variables: }}{\text { Industrial growth rate }}$ & INDGR & Annual percentage increase in industrial production of Pakistan \\
\hline Growth in Gross domestic product & GGDP & Annual GDP growth rate \\
\hline Inflation rate & INF & Annual rate of inflation \\
\hline
\end{tabular}

\section{Appendix B}

Table A2. Life cycle wise distribution of sampled data.

\begin{tabular}{ccc}
\hline Life Cycle Stage & Number of Firm-Year Observations & Percentage \\
\hline Introduction & 414 & $17.46 \%$ \\
Growth & 411 & $17.33 \%$ \\
Mature & 1025 & $43.23 \%$ \\
Shake-out & 389 & $16.40 \%$ \\
Decline & 132 & $5.56 \%$ \\
\hline Total & 2371 & $100 \%$ \\
\hline
\end{tabular}

\section{References}

1. Lourenço, I.C.; Branco, M.C.; Curto, J.D.; Eugénio, T. How does the market value corporate sustainability performance? J. Bus. Ethics 2012, 108, 417-428. [CrossRef]

2. IMF. IMF Survey: Sharp Rise in Unemployment from Global Recession; International Monetary Fund: Oslo, Norway, 2010.

3. Anbumozh, V.; Bauer, A. Impact of Global Recession on Sustainable Development and Poverty Linkages; ADBI Working Paper 227; ADBI: Chiyoda, Tokyo, 2010.

4. Soppe, A. Sustainable corporate finance. J. Bus. Ethics 2004, 53, 213-224. [CrossRef]

5. Opler, T.; Pinkowitz, L.; Stulz, R.; Williamson, R. The determinants and implications of corporate cash holdings. J. Financ. Econ. 1999, 52, 3-46. [CrossRef]

6. Peel, M.J.; Wilson, N. Working capital and financial management practices in the small firm sector. Int. Small Bus. J. 1996, 14, 52-68. [CrossRef]

7. Petersen, M.A.; Rajan, R.G. Trade credit: Theories and evidence. Rev. Financ. Stud. 1997, 10, 661-691. [CrossRef]

8. Kim, Y.H.; Chung, K.H. An integrated evaluation of investment in inventory and credit: A cash flow approach. J. Bus. Finan. Acc. 1990, 17, 381-389. [CrossRef]

9. Lee, Y.W.; Stowe, J.D. Product risk, asymmetric information, and trade credit. J. Financ. Quant. Anal. 1993, 28, 285-300. [CrossRef]

10. Knauer, T.; Wöhrmann, A. Working capital management and firm profitability. J. Manag. Contr. 2013, 24, 77-87. [CrossRef] 
11. Appuhami, B.R. The impact of firms' capital expenditure on working capital management: An empirical study across industries in Thailand. Int. Manag. Rev. 2008, 4, 8.

12. Smith, K. Profitability versus liquidity tradeoffs in working capital management. In Readings on the Management of Working Capital; West Pub. Co.: Eagan, MN, USA, 1980; pp. 549-562.

13. Kieschnick, R.; Laplante, M.; Moussawi, R. Working capital management and shareholders' wealth. Rev. Financ. 2013, 17, 1827-1852. [CrossRef]

14. Wang, Y.-J. Liquidity management, operating performance, and corporate value: Evidence from Japan and Taiwan. J. Multinatl. Financ. Manag. 2002, 12, 159-169. [CrossRef]

15. Chittenden, F.; Poutziouris, P.; Michaelas, N. Financial Management and Working Capital Practices in UK SMEs; Manchester Business School: Manchester, UK, 1998.

16. Chandler, A.D. Strategy and Structure; MIT Press: Cambridge, MA, USA, 1962.

17. Warusawitharana, M. Profitability and the Lifecycle of Firms. BE J. Macroecon. 2018, 18. [CrossRef]

18. Berger, A.N.; Udell, G.F. The economics of small business finance: The roles of private equity and debt markets in the financial growth cycle. J. Bank. Financ. 1998, 22, 613-673. [CrossRef]

19. Richardson, S. Over-investment of free cash flow. Rev. Acc. Stud. 2006, 11, 159-189. [CrossRef]

20. Akbar, A.; Akbar, M.; Tang, W.; Qureshi, M.A. Is Bankruptcy Risk Tied to Corporate Life-Cycle? Evidence from Pakistan. Sustainability 2019, 11, 678. [CrossRef]

21. Deloof, M. Does working capital management affect profitability of Belgian firms? J. Bus. Financ. Account. 2003, 304, 573-588. [CrossRef]

22. Pais, M.A.; Gama, P.M. Working capital management and SMEs profitability: Portuguese evidence. Int. J. Manag. Financ. 2015, 11, 341-358. [CrossRef]

23. Nazir, M.S.; Afza, T. Impact of aggressive working capital management policy on firms' profitability. Iup J. Appl. Financ. 2009, 15, 19.

24. Bulan, L.; Yan, Z. The pecking order of financing in the firm's life cycle. Bank. Financ. Lett. 2009, 1, 129-140.

25. Faff, R.; Kwok, W.C.; Podolski, E.J.; Wong, G.J. Do corporate policies follow a life-cycle? J. Bank. Financ. 2016, 69, 95-107. [CrossRef]

26. Habib, A.; Hasan, M.M. Corporate life cycle research in accounting, finance and corporate governance: A survey, and directions for future research. Int. Rev. Financ. Anal. 2019, 61, 188-201. [CrossRef]

27. Chen, C.; Kieschnick, R. Bank credit and corporate working capital management. J. Corp. Financ. 2018, 48, 579-596. [CrossRef]

28. World Bank. World Development Indicators; World Bank: Washington, DC, USA, 2016.

29. World Bank Enterprise Survey. Available online: https://data.worldbank.org/indicator/IC.FRM.BKWC.ZS? end $=2018 \&$ start $=2011 \&$ view $=$ chart (accessed on 7 October 2019).

30. Baños-Caballero, S.; García-Teruel, P.J.; Martínez-Solano, P. Working capital management, corporate performance, and financial constraints. J. Bus. Res. 2014, 67, 332-338. [CrossRef]

31. Sial, M.; Chaudhry, A. Relationship between Working Capital Management and Firm Profitability: Manufacturing Sector of Pakistan. 2012. Available online: https://papers.ssrn.com/sol3/papers.cfm?abstract_ id=2105638 (accessed on 27 December 2019).

32. Arshad, Z.; Gondal, M.Y. Impact of working capital management on profitability a case of the Pakistan cement industry. Interd. J. Contemp. Res. Bus. 2013, 5, 384-390.

33. Iqbal, A.; Zhuquan, W. Working Capital Management and its Impact on Firm's Performance. Int. J. Bus. Soc. Sci. 2014, 5, 123-130.

34. Tahir, M.; Anuar, M.B.A. The determinants of working capital management and firm's performance of textile sector in Pakistan. Qual. Quant. 2016, 50, 605-618. [CrossRef]

35. Enqvist, J.; Graham, M.; Nikkinen, J.J.R. The impact of working capital management on firm profitability in different business cycles: Evidence from Finland. Res. Int. Bus. Financ. 2014, 32, 36-49. [CrossRef]

36. Tsuruta, D.J.J.; Economy, T.W. Working capital management during the global financial crisis: Evidence from Japan. Jpn. World Econ. 2019, 49, 206-219. [CrossRef]

37. Bogan, V.; Johnson, W.; Mhlanga, N. Does Capital Structure affect the financial sustainability of Microfinance Institutions? 2007. Available online: https:/pdfs.semanticscholar.org/67d8/ 3ce37b962edcbfa40469e435c8093f0f90c3.pdf (accessed on 17 February 2019).

38. Bonazzi, G.; Iotti, M. Interest coverage ratios (ICRs) and financial sustainability: Application to firms with bovine dairy livestock. Am. J. Agric. Biol. Sci. 2014, 9, 482. [CrossRef] 
39. Njeri, W.R.; Namusonge, G.; Mugambi, F. Effect of working capital management on financial sustainability of government owned entities in the ministry of agriculture, livestock and fisheries (MOALF), Kenya. Strateg. J. Bus. Chang. Manag. 2017, 4, 3.

40. Miller, D.; Friesen, P.H. A longitudinal study of the corporate life cycle. Manag. Sci. 1984, 30, 1161-1183. [CrossRef]

41. Spence, A.M. Entry, capacity, investment and oligopolistic pricing. Bell J. Econ. 1977, 8, 534-544. [CrossRef]

42. Frielinghaus, A.; Moster, B.; Firer, C. Capital Structure and firm's life stage. S. Afr. J. Bus. Manag. 2005, 36, 10. [CrossRef]

43. Marshall, J.; Heffes, E.M. Business continuity: Smaller firms most vulnerable to problems. Financ. Exec. 2004, 20, 11-12.

44. Carpenter, R.E.; Petersen, B.C. Is the growth of small firms constrained by internal finance? Rev. Econ. Stat. 2002, 84, 298-309. [CrossRef]

45. Liao, Y. The effect of fit between organizational life cycle and human resource management control on firm performance. J. Am. Acad. Bus. 2006, 8, 192-196.

46. Petersen, M.A.; Rajan, R.G. The effect of credit market competition on lending relationships. Q. J. Econ. 1995, 407-443. [CrossRef]

47. Lemmon, M.L.; Zender, J.F. Debt capacity and tests of capital structure theories. J. Financ. Quant. Anal. 2010, 45, 1161-1187. [CrossRef]

48. Hasan, M.M.; Hossain, M.; Habib, A. Corporate life cycle and cost of equity capital. J. Contemp. Acc. Econ. 2015, 11, 46-60. [CrossRef]

49. Tian, L.; Han, L.; Zhang, S. Business life cycle and capital structure: Evidence from Chinese manufacturing firms. China World Econ. 2015, 23, 22-39. [CrossRef]

50. Primc, K.; Čater, T. Environmental strategies in different stages of organisational evolution: Theoretical foundations. Australas. J. Environ. Manag. 2016, 23, 100-117. [CrossRef]

51. Habib, A.; Hasan, M.M. Firm life cycle, corporate risk-taking and investor sentiment. Account. Financ. 2015. [CrossRef]

52. Dickinson, V. Cash flow patterns as a proxy for firm life cycle. Acc. Rev. 2011, 86, 1969-1994. [CrossRef]

53. Ronda-Pupo, G.A.; Guerras-Martin, L.Á. Dynamics of the evolution of the strategy concept 1962-2008: A co-word analysis. Strat. Manag. J. 2012, 33, 162-188. [CrossRef]

54. Talonpoika, A.-M.; Kärri, T.; Pirttilä, M.; Monto, S.; Michayluk, D. Defined strategies for financial working capital management. Int. J. Manag. Financ. 2016, 12. [CrossRef]

55. Baños-Caballero, S.; García-Teruel, P.J.; Martínez-Solano, P. How does working capital management affect the profitability of Spanish SMEs? Small Bus. Econ. 2012, 39, 517-529. [CrossRef]

56. Blinder, A.S.; Maccini, L.J. The resurgence of inventory research: What have we learned? J. Econ. Surv. 1991, 5, 291-328. [CrossRef]

57. Soenen, L.A. Cash conversion cycle and corporate profitability. J. Cash Manag. 1993, 13, 53.

58. Afrifa, G.A. Working Capital Management and AIM Listed SME Companies Profitability: A Mixed Research Method Approach; Bournemouth University: Poole, UK, 2013.

59. Autukaite, R.; Molay, E. In Cash Holdings, Working Capital and Firm Value: Evidence from France. In Proceedings of the International Conference of the French Finance Association (AFFI), Montpellier, France, 11-13 May 2011.

60. Shin, H.-H.; Soenen, L. Efficiency of working capital management and corporate profitability. Financ. Pr. Educ. 1998, 8, 37-45.

61. Hassani, M.; Bagherian, J.M. An investigation the role of Life Cycle on the relationship between. Acad. J. Res. Bus. Account. 2014, 4, 35-47.

62. Garson, G.D. Hierarchical Linear Modeling: Guide and Applications; Sage: Thousand Oaks, CA, USA, 2012.

63. Goldstein, H. Multilevel Statistical Models; John Wiley \& Sons: Hoboken, NJ, USA, 2011; Volume 922.

64. Hsiao, C. Benefits and limitations of panel data. Econ. Rev. 1985, 4, 121-174. [CrossRef]

65. Kennedy, P. Guide to Econometrics, 6th ed.; Wiley-Blackwell: Oxford, UK, 2008.

66. Ahsan, T.; Wang, M.; Qureshi, M.A. How do they adjust their capital structure along their life cycle? An empirical study about capital structure over life cycle of Pakistani firms. J. Asia Bus. Stud. 2016, 10, 276-302. [CrossRef] 
(C) 2020 by the authors. Licensee MDPI, Basel, Switzerland. This article is an open access article distributed under the terms and conditions of the Creative Commons Attribution (CC BY) license (http://creativecommons.org/licenses/by/4.0/). 